\title{
Docking Applications for Some Novel Complexes Derived From New Quinoline Derivatives
}

\author{
Ibrahim A. I. Ali ${ }^{1}$, Sahar A.S. El-Sakka ${ }^{2}$, Mohamed Helmy ${ }^{2}$, Omayma E. A. Mohmed ${ }^{3 *}$ \\ ${ }^{1}$ Suez Canal University, Faculty of Science, Chemistry Department, Ismailia, Egypt \\ ${ }^{2}$ Suez Universities, Faculty of Science, Chemistry Department, Suez, Egypt \\ ${ }^{3}$ Chemistry Administrations, Suez, Egypt
}

\begin{abstract}
The new quinoline derivatives: 2-oxo-1,2-dihydroquinoline-4-carbohydrazide (1),2-(allyloxy)quinoline-4carbohydrizde (2), 1-allyl-2-oxo-1,2-dihydroquinoline-4-carbohydrazid (3) and 2-(allyl-thio)quinoline-4carbohydrazide (4) and their $\mathrm{Cu}(\mathrm{II}), \mathrm{Ni}$ (II) and $\mathrm{Co}(\mathrm{II})$ complexes were synthesized and characterized by using elemental analysis (CHNM\%), FTIR, UV/Vis, ${ }^{1} \mathrm{HNMR},{ }^{13} \mathrm{CNMRspectra,} \mathrm{DTA,} \mathrm{TGA,} \mathrm{magnetic}$ susceptibility and the conductivity of $0.001 \mathrm{M}$ in DMSO. The FTIR spectra of the synthesized ligands and their complexes were giving the characteristic stretching vibration bands. The weight loss which appeared in the TG analysis indicates that, there are different types of water molecules in the formed complexes. The theoretical calculations which carried out using different computer programs permit proposing an optimized geometry for the formed complexes. The molecular modeling for the free ligands and their complexes were evaluated and discussed. Docking of the synthesized compounds with HepG2-code:5EQG protein, as liver carcinoma cell, gave promising inhibition in Silico level. The antimicrobial activity of the target compounds with E. Coli, Bacillus subtilis and Aspergillus niger, in Vitro level, gave promising result. The interaction of the compounds with the microorganisms was tested in Silico level. E. Coli was used as an example for the target microorganism. The protein which used for docking process was 5C9T.

Keywords: 5C9T, 5EQG, Antimicrobial, Complexes, Docking, In Silico, Quinoline.
\end{abstract}

\section{INTRODUCTION}

The synthesis of quinoline and its derivatives have attracted considerable attention of organic and medicinal chemists for many years (Kouznetsov et al., 2005). The structural core of quinoline is frequently associated with medicinal applications (Bénard et al., 2004; Borioni et al., 2007; Desrivot et al., 2007; Musiol et al., 2006). The intensive efforts to find effective therapeutic agents with antiviral and antitumor activities have directed many researchers to synthesize a series of quinoline derivatives or their analogues.

The prevalence of the quinoline ring system in a vast range of medical and industrial setting scan is ascribed mainly to its versatility and broad potential for functionalization. In fact, this versatility which earned it the designation of "privileged scaffold" in medicinal chemistry, a term coined by Evans in 1988 which refers to simple structural subunits present in diverse therapeutic compounds with distinctive receptor affinities (Evans et al., 1988). Consequently, the synthesis of variously substituted quinolines has been a recurring endeavor for nearly a century and a half (Bräse, 2015). A multitude of synthetic methods have been established over this timeframe, which construct the quinoline ring from diverse starting materials and result in products with nearly limitless combinations of functionality.

Recently it is reported that quinoline hydrazones and their $\mathrm{Zn}$ (II) complexes showed significant activity against the Mycobacterium tuberculosis strain, at low micro-molar levels (Mandewale et al., 2015; Thomas et al., 2011; Vavř́iková et al., 2011).

Recent years have witnessed an unprecedented progress in biological applications of metal coordination compounds of biologically active ligands because of their key role in clinical therapy. Transition metals are particularly suitable for this purpose because they can adopt a wide variety of coordination numbers, geometries and oxidation states in comparison with other main group elements. One of the characteristics of metals is their potential to undergo redox processes, as determined by their redox potentials. Especially, transition metal ions are usually able to switch between several oxidation states. Due to the redox activity of metals and, therefore, a possible disturbance of the sensitive cellular redox homeostasis, a tight regulation of the metal and redox balance is crucial for health (Kostova and Balkansky, 2013).

Depending on their structure and on the source of the oxidative stress, metal complexes might act as antioxidants or pro oxidants. The current review provides insight into the interaction between the reactive oxygen species and the transition metals and their complexes. It will focus on a novel approach to design synthetic antioxidant metal-based compounds and to study their activities in the oxidation processes. This work underlines some important features for the research on metal complexes of biologically active ligands and supports future evaluation of some of these compounds as possible therapeutic agents (Kostova and Balkansky, 2013).

According to the history of the important applications of the quinoline derivatives and their metal complexes, this work introduce some new quinoline derivatives and their $\mathrm{Cu}^{2+}, \mathrm{Ni}^{2+}$ and $\mathrm{Co}^{2+}$ complexes. The new view of the synthesized compounds in the level of in Vitro and in Silico was attained to deep prospective view which facilitate to decide which could be used as drug and which could be toxic.

\section{Materials}

\section{MATERIALS AND METHODS}

All chemicals used in this study were of analytical 
grade. The primitive chemicals (Koch-Light and Sigma - Aldrich) were used as received. The metals nitrate salts $(\mathrm{Cu}(\mathrm{II}), \mathrm{Ni}(\mathrm{II}), \mathrm{Co}(\mathrm{II}))$ were purchased from the Sigma-Aldrich and used without extra treatment.

\section{Apparatus}

Thin layer chromatography (TLC) was carried out on silica gel type $60-\mathrm{F}_{254}$ aluminum sheets (E. Merck, layer thickness $=0.2 \mathrm{~mm}$ ) using the following solvent systems, $\mathrm{S} 1$ : petroleum ether/ethyl acetate $(5: 1) ; \mathrm{S}_{2}$ : petroleum ether/ethyl acetate $(2: 1) ; \mathrm{S}_{3}$ : petroleum ether/ethyl acetate $(1: 1)$.

The obtained spots were detected by UV lamp. Melting points were determined on $300{ }^{\circ} \mathrm{C}$ melting point apparatus and the values are used without extra correction. The infrared spectra were obtained in the $4000-400 \mathrm{~cm}^{-1}$ region by using Bruker Alpha instrument with $\mathrm{KBr}$ discs. ${ }^{1} \mathrm{H}$ and ${ }^{13} \mathrm{CNMR}$ spectra were recorded on Bruker spectrometer operating at 300 and 75.0 $\mathrm{MHz}$ uses $\mathrm{CDCl}_{3}$ as solvent and TMS as internal standard. Elemental analysis was carried out by elementarvario instrument. The electronic absorption spectra were obtained on UV-1601PC Shimadzu spectrophotometer in $1 \mathrm{~cm}$ quartz cell. TGA and DTA were recorded on Shimadzu 60 thermal analyzer under a dynamic flow of nitrogen $(30 \mathrm{ml} / \mathrm{min})$ and heating rate $10{ }^{\circ} \mathrm{C} / \mathrm{min}$ with open platinum sample holder. Electrical conductivity measurements were carried out at room temperature on freshly prepared $1 \mathrm{mM}$ DMSO solution using a WTW conductivity.

\section{Antimicrobial Activity}

The antimicrobial activities of the synthesized compounds have been screened using different strains of bacteria (Bacillis subtilis and Escherichia coli) and pathogenic fungi (Aspergillus fumigatus). The disc diffusion method technique was adapted for antibacterial activity (Barry and Brown, 1996) while the well technique was used for antifungal activity (Cruickshank et al., 1965). Mean zone of the inhibition in $\mathrm{mm}$ \pm standard deviation beyond well diameter $(6 \mathrm{~mm})$ produced on a range of environmental and clinically pathogenic microorganisms using $(30 \mathrm{mg} / \mathrm{L})$ concentration of the tested samples. The test was done using the diffusion agar technique, well diameter: $6.0 \mathrm{~mm}(30 \mu \mathrm{L}$ was tested). Ampicillin and Fluconazole were used as positive control while methanol was used as negative control. This test was performed in the Center of Mycology and Biotechnology -Suez Canal University.

\section{Synthesis of the Target Complexes}

The target complexes were prepared according to the following procedure. The targeted compounds (ligands) $(1.0 \mathrm{mmol})$ were dissolved in $20 \mathrm{ml}$ ethanol. The metal nitrate $(0.5 \mathrm{mmol})$ was dissolved in $10 \mathrm{ml}$ ethanol, which was added dropwise with stirring to the ligand solution. The obtained mixture was refluxed with stirring for $5 \mathrm{hrs}$. The formed precipitate was filtered, washed with hot ethanol and dried under vacuum over anhydrous $\mathrm{CaCl}_{2}$.

\section{Synthesis of the Target Quinoline derivatives}

Synthesis of 2-oxo-1,2-dihydroquinoline-4-carbohydrazide (1)

To a solution of ester (A) $(0.5 \mathrm{~g}, 2.46 \mathrm{mmol})$ in ethanol $(20 \mathrm{ml})$, was added hydrazine hydrate $(1 \mathrm{ml}$, $20.55 \mathrm{mmol})$. The reaction mixture was refluxed at 85 ${ }^{\circ} \mathrm{C}$ for $6 \mathrm{~h}$, after cooling to room temperature the precipitated hydrazide was filtered off, washed with water and ethanol followed by recrystallization from aqueous ethanol to yield: 2-oxo-1,2-dihydroquinoline4-carbohydrazide (1) (Scheme 1), fainty beige powder (1.59 g, 88.3\%), mp > $300{ }^{\circ} \mathrm{C}, \mathrm{R}_{\mathrm{f}}=0.90\left(\mathrm{~S}_{2}\right),{ }^{1} \mathrm{HNMR}$ $\left(300.0 \mathrm{MHz}, \mathrm{CDCl}_{3}\right) \delta=9.96(2 \mathrm{H}, \mathrm{br}, 2 \mathrm{NH}), 7.75(1 \mathrm{H}$, $\mathrm{d}, \mathrm{J}=9.0 \mathrm{~Hz}, \mathrm{ArH}), 7.54(1 \mathrm{H}, \mathrm{t}, \mathrm{J}=9.0 \mathrm{~Hz}, \operatorname{ArH}), 7.36$ $(1 \mathrm{H}, \mathrm{d}, \mathrm{J}=6.0, \mathrm{ArH}), 7.19(1 \mathrm{H}, \mathrm{t}, \mathrm{J}=9.0 \mathrm{~Hz}, \mathrm{ArH})$, $6.48(1 \mathrm{H}, \mathrm{s}, \mathrm{ArH}), 4.55,3.45\left(2 \mathrm{H}, \mathrm{br}, \mathrm{NH}_{2}\right) .{ }^{13} \mathrm{CNMR}$ $\left(75.0 \mathrm{MHz}, \mathrm{CDCl}_{3}\right) \delta=165.5(\mathrm{CO}), 161.6$ (Ar-CO), $145.5,139.6,131.3,126.4,122.4,120.5,116.8,116.1$ (Ar-C). Anal. Calc. for $\mathrm{C}_{10} \mathrm{H}_{9} \mathrm{~N}_{3} \mathrm{O}_{2}$ (203.20): C, 59.11; H, 4.46; N, 20.68. Found: C, 59.34; H, 4.18; N, 20.45. (2)

Synthesis of 2-(allyloxy) quinoline-4-carbohydrazide

To a solution of ester (B) $(1.6 \mathrm{~g}, 6.5 \mathrm{mmol})$ in methanol (30 $\mathrm{ml})$, hydrazine hydrate $(2 \mathrm{ml}, 41.11 \mathrm{mmol})$ was added. The reaction mixture was refluxed for $6 \mathrm{~h}$. After cooling to room temperature, the precipitated hydrazide was filtered off, washed with water and methanol followed by crystallization from aqueous methanol to yield: 2-(allyloxy)quinoline-4-carbohydrazide (2) (Scheme 1), white powder $(1.2 \mathrm{~g}, 75.0 \%)$, m.p $168{ }^{\circ} \mathrm{C}$, $\mathrm{R}_{\mathrm{f}}=0.67\left(\mathrm{~S}_{2}\right) .{ }^{1} \mathrm{HNMR}\left(300.0 \mathrm{MHz}, \mathrm{CDCl}_{3}\right) \delta=9.88$ $(1 \mathrm{H}$, br, NH), $8.05(1 \mathrm{H}, \mathrm{d}, \mathrm{J}=9.0 \mathrm{~Hz}, \mathrm{ArH}), 7.80(1 \mathrm{H}$, $\mathrm{d}, \mathrm{J}=9.0 \mathrm{~Hz}, \mathrm{ArH}), 7.72-7.67$ (1H, m, ArH), 7.48-7.43 $(1 \mathrm{H}, \mathrm{m}, \mathrm{ArH}), 6.97(1 \mathrm{H}, \mathrm{s}, \mathrm{ArH}), 6.25-6.12(1 \mathrm{H}, \mathrm{m}$, $\mathrm{CH}=), 5.52,5.34\left(2 \mathrm{H}, 2 \mathrm{~d}, \mathrm{~J}=18.0,12.0 \mathrm{~Hz},=\mathrm{CH}_{2}\right)$, $5.06\left(2 \mathrm{H}, \mathrm{d}, \mathrm{CH}_{2} \mathrm{O}\right), 4.66\left(2 \mathrm{H}, \mathrm{br}, \mathrm{NH}_{2}\right) .{ }^{13} \mathrm{CNMR}(75.0$ $\left.\mathrm{MHz}, \mathrm{CDCl}_{3}\right) \delta=165.8$ (CO), 161.5 (Ar-CO), 146.8, 144.6 (Ar-C), 133.3 (CH=), 130.5, 127.5, 125.9, 124.9, 122.1 (Ar-C), $117.8 \quad\left(=\mathrm{CH}_{2}\right), 111.7 \quad$ (Ar-C), 67.7 $\left(\mathrm{OCH}_{2}\right)$. Anal. Calcd. For $\mathrm{C}_{13} \mathrm{H}_{13} \mathrm{~N}_{3} \mathrm{O}_{2}$ (243.27): C, 64.4; H, 5.39; N, 17.27. Found: C, 64.02; H, 5.69; N, 17.46 .

Synthesis of 1-allyl-2-oxo-1,2-dihydroquinoline-4carbohydrazide (3)

To a solution of ester $(\mathrm{C})(1.2 \mathrm{~g}, 4.9 \mathrm{mmol})$ in methanol (30 ml),hydrazine hydrate $(2 \mathrm{ml}, 41.11 \mathrm{mmol})$ was added, the reaction mixture was refluxed for $6 \mathrm{~h}$, cooled to room temperature the resultant precipitated form was filtered off, washed with water and methanol followed by crystallization from aqueous methanol to afford 1allyl-2-oxo-1,2dihydroquinoline-4-carbohydrazid (3) (Scheme 1), yellow crystals $(0.65$ g, 54.2\%), m.p 267 $269{ }^{\circ} \mathrm{C}, \mathrm{R}_{\mathrm{f}}=0.50\left(\mathrm{~S}_{3}\right) .{ }^{1} \mathrm{HNMR}\left(300.0 \mathrm{MHz}, \mathrm{CDCl}_{3}\right)$ $\delta=9.90(1 \mathrm{H}, \mathrm{s}, \mathrm{NH}), 7.82(1 \mathrm{H}, \mathrm{d}, \mathrm{J}=9.0 \mathrm{~Hz}, \mathrm{ArH})$, $7.63(1 \mathrm{H}, \mathrm{t}, \mathrm{J}=9.0 \mathrm{~Hz}, \operatorname{ArH}), 7.50(1 \mathrm{H}, \mathrm{d}, \mathrm{J}=9.0 \mathrm{~Hz}$, $\operatorname{ArH}), 7.28(1 \mathrm{H}, \mathrm{t}, \mathrm{J}=9.0 \mathrm{~Hz}, \mathrm{ArH}), 6.61(1 \mathrm{H}, \mathrm{s}, \operatorname{ArH})$, 6.00-5.88 (1H, m, CH=), 5.16, $5.00(2 \mathrm{H}, 2 \mathrm{~d}, \mathrm{~J}=12.0$, $\left.18.0 \mathrm{~Hz},=\mathrm{CH}_{2}\right), 4.93\left(2 \mathrm{H}, \mathrm{d}, \mathrm{J}=6.0 \mathrm{~Hz}, \mathrm{CH}_{2} \mathrm{~N}\right), 4.63$ $\left(2 \mathrm{H}, \mathrm{s}, \mathrm{NH}_{2}\right) .{ }^{13} \mathrm{CNMR}\left(75.0 \mathrm{MHz}, \mathrm{CDCl}_{3}\right)=165.4$ (CO), 160.6 (Ar-CO), 144.8, 139.5 (Ar-C), 132.8 $(\mathrm{CH}=)$, 131.6, 127.2, 122.6, 119.6, 117.9 (Ar-C), 117.0 $\left(=\mathrm{CH}_{2}\right), 116.0(\mathrm{Ar}-\mathrm{C}), 44.1\left(\mathrm{NCH}_{2}\right)$. Anal. Calcd. for $\mathrm{C}_{13} \mathrm{H}_{13} \mathrm{~N}_{3} \mathrm{O}_{2}$ (243.27): C, 64.4; H, 5.39; N. 17.27. Found: C, 64.27; H, 5.55; N, 17.41. 


\section{(4)}

Synthesis of 2-(allylthio) quinoline-4-carbohydrazide

To a solution of ester (D) (1.2g, $4.6 \mathrm{mmol})$ in methanol $(30 \mathrm{ml})$, was added hydrazine hydrate $(2 \mathrm{ml}, 41.11$ $\mathrm{mmol})$. The reaction mixture was refluxed for $6 \mathrm{~h}$. After cooling to room temperature, the resultant precipitate was filtered off, washed with water and methanol followed by crystallization from aqueous methanol to give of 2-(allylthio)quinoline-4-

carbohydrazide (4) (Scheme 1), Beige powder (1 g, $83.3 \%)$, m.p $=156-158{ }^{\circ} \mathrm{C}, \mathrm{R}_{\mathrm{f}}=0.64,\left(\mathrm{~S}_{1}\right) .{ }^{1} \mathrm{HNMR}$ $\left(300.0 \mathrm{MHz}, \mathrm{CDCl}_{3}\right)=8.50(1 \mathrm{H}, \mathrm{d}, \mathrm{NH} \leftrightarrow \mathrm{OH}), 8.09$ $(1 \mathrm{H}, \mathrm{d}, \mathrm{J}=6.0 \mathrm{~Hz}, \mathrm{Ar}-\mathrm{H}), 7.93(1 \mathrm{H}, \mathrm{d}, \mathrm{J}=9.0 \mathrm{~Hz}, \mathrm{ArH}$ ), $7.75(1 \mathrm{H}, \mathrm{t}, \mathrm{J}=6.0 \mathrm{~Hz}, \mathrm{ArH}), 7.54(1 \mathrm{H}, \mathrm{t}, \mathrm{J}=6 \mathrm{~Hz}$, $\mathrm{ArH}), 7.35(1 \mathrm{H}, \mathrm{s}, \mathrm{ArH}), 6.10-5.95(1 \mathrm{H}, \mathrm{m}, \mathrm{CH}=)$, $5.45,5.15\left(2 \mathrm{H}, 2 \mathrm{~d}, \mathrm{~J}=15.0,9.0 \mathrm{~Hz},=\mathrm{CH}_{2}\right), 4.30(2 \mathrm{H}$, br, $\left.\mathrm{NH}_{2}\right), 4.02\left(2 \mathrm{H}, \mathrm{d}, \mathrm{J}=6.0 \mathrm{~Hz}, \mathrm{SCH}_{2}\right) .{ }^{13} \mathrm{CNMR}$ $\left(75.0 \mathrm{MHz}, \mathrm{CDCl}_{3}\right)=165.7(\mathrm{CO}), 158.4(\mathrm{CS}), 148.3$, 141.3 (Ar-C), $134.2(\mathrm{CH}=), 130.7,128.3,126.4$, 126.0, 122.9, 14.1 (Ar-C), $118.5\left(=\mathrm{CH}_{2}\right), 32.3\left(\mathrm{SCH}_{2}\right)$. Anal. Calcd. for $\mathrm{C}_{13} \mathrm{H}_{13} \mathrm{~N}_{3} \mathrm{OS}$ (259.33): C, 60.21; H, 5.05; N; 16.20. Found: C, 60.32; H, 5.17; N, 16.43.<smiles>NNC(=O)c1cc(=O)[nH]c2ccccc12</smiles>

(1)

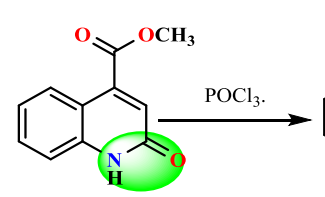

(A)

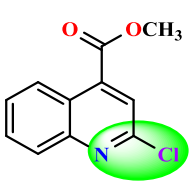

(5)
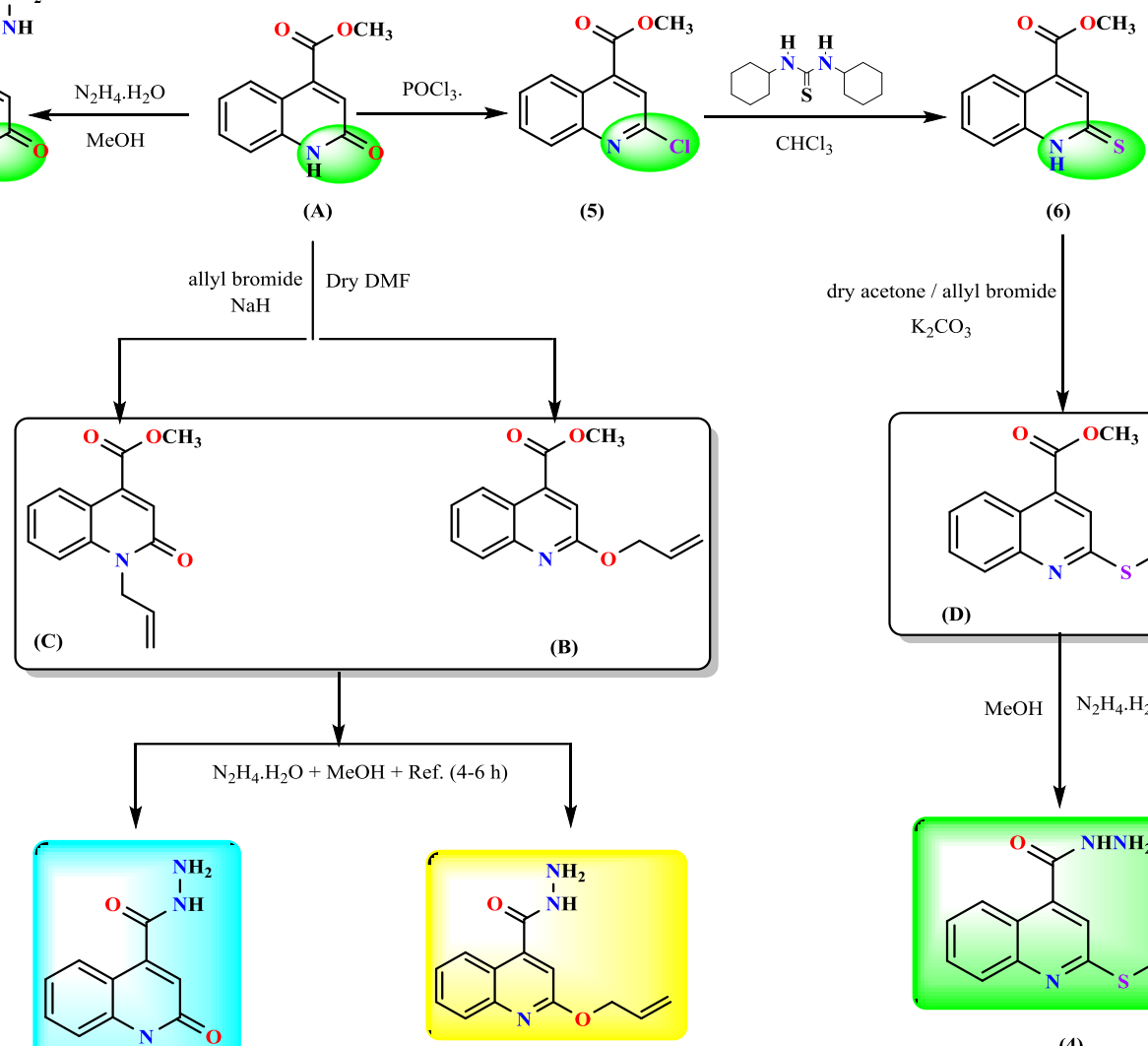

(2)

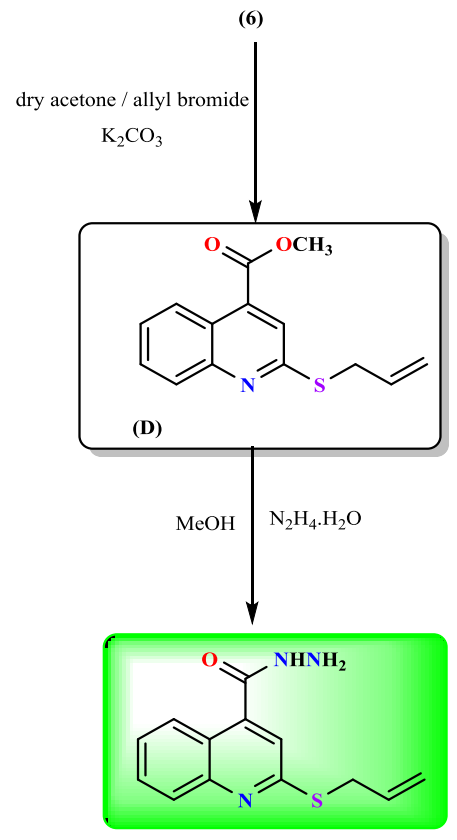

(4)

Scheme 1: The stepwise formation of the synthesized ligands 1-4. 


\section{RESULTS AND DISCUSSION}

The obtained complexes which formed from the reaction of the target ligands (1-4) with the $\mathrm{M}$ (II) ions $(\mathrm{M}=\mathrm{Cu}, \mathrm{Ni}$ and $\mathrm{Co})$ were purified and characterized by using different tools, which depicted as the following:

\section{Elemental Analysis and Physical Properties}

The elemental analysis of the complexes which formed from the ligand $\mathbf{1}$ and M(II) ions was listed in Table 1. The postulated formula could be represented as the following: ....... $\left.\mathrm{Co}\left(\mathrm{C}_{10} \mathrm{H}_{9} \mathrm{~N}_{3} \mathrm{O}_{2}\right)_{2}\left(\mathrm{H}_{2} \mathrm{O}\right)_{2}\right](\mathrm{NO} 3)_{2}$, $\left[\mathrm{Ni}\left(\mathrm{C}_{10} \mathrm{H}_{9} \mathrm{~N}_{3} \mathrm{O}_{2}\right)_{2}\left(\mathrm{H}_{2} \mathrm{O}\right)_{2}\right]\left(\mathrm{NO}_{3}\right)_{2}$ ........... and $\left[\mathrm{Cu}\left(\mathrm{C}_{10} \mathrm{H}_{9} \mathrm{~N}_{3} \mathrm{O}_{2}\right)_{2}\right]\left(\mathrm{NO}_{3}\right)_{2} \cdot\left(\mathrm{H}_{2} \mathrm{O}\right)_{2} . \mathrm{Co}(\mathrm{II})$ complexes formed as cream non-hygroscopic crystals, $\mathrm{Ni}$ (II) as ice blue crystals and $\mathrm{Cu}(\mathrm{II})$ as green crystals.

The interaction of the ligand $2\left(\mathrm{C}_{13} \mathrm{H}_{13} \mathrm{~N}_{3} \mathrm{O}_{2}\right)$ with the $\mathrm{Co}(\mathrm{II}), \mathrm{Ni}(\mathrm{II})$ and $\mathrm{Cu}(\mathrm{II})$ ions gave the corresponding complexes which could be formulated as:.

................... $\left[\mathrm{Co}\left(\mathrm{C}_{13} \mathrm{H}_{13} \mathrm{~N}_{3} \mathrm{O}_{2}\right)_{2}\left(\mathrm{H}_{2} \mathrm{O}\right)_{2}\right]\left(\mathrm{NO}_{3}\right)_{2}$ $\left[\mathrm{Ni}\left(\mathrm{C}_{13} \mathrm{H}_{13} \mathrm{~N}_{3} \mathrm{O}_{2}\right)_{2}\left(\mathrm{H}_{2} \mathrm{O}\right)_{2}\right]\left(\mathrm{NO}_{3}\right)_{2}$

and $\left[\mathrm{Cu}\left(\mathrm{C}_{13} \mathrm{H}_{13} \mathrm{~N}_{3} \mathrm{O}_{2}\right)_{2}\right]\left(\mathrm{NO}_{3}\right)_{2} \cdot\left(\mathrm{H}_{2} \mathrm{O}\right)_{4}$ respectively.

The obtained elemental analysis ( $\mathrm{N}$ and $\mathrm{M} \%$ ) go well with the postulated formula (Table 1). All the complexes were crystalline and non-hygroscopic. $\mathrm{Co}$ (II) complex has brown fine crystals, $\mathrm{Ni}$ (II) and $\mathrm{Cu}(\mathrm{II})$ complexes gave green crystal.

The complexes which derived from the ligand $\mathbf{3}$ and the target metals ions gave elemental analysis as shown in Table 1. The obtained results revealed the following postulated formula: $\left[\mathrm{Co}\left(\mathrm{C}_{13} \mathrm{H}_{13} \mathrm{~N}_{3} \mathrm{O}_{2}\right)_{2}\left(\mathrm{H}_{2} \mathrm{O}\right)_{2}\right]\left(\mathrm{NO}_{3}\right)_{2}$, .................. $\left[\mathrm{Ni}\left(\mathrm{C}_{13} \mathrm{H}_{13} \mathrm{~N}_{3} \mathrm{O}_{2}\right)_{2}\left(\mathrm{H}_{2} \mathrm{O}\right)_{2}\right]\left(\mathrm{NO}_{3}\right)_{2}$ and $\left[\mathrm{Cu}\left(\mathrm{C}_{13} \mathrm{H}_{13} \mathrm{~N}_{3} \mathrm{O}_{2}\right)_{2}\right]\left(\mathrm{NO}_{3}\right)_{2}$. $\left(\mathrm{H}_{2} \mathrm{O}\right)_{2}$. All the complexes have fine crystal structure and non-hygroscopic behavior. Co(II) complex has orange color, Ni(II) complex was ice blue meanwhile $\mathrm{Cu}(\mathrm{II})$ was turquoise.

The interaction of the ligand $4\left(\mathrm{C}_{13} \mathrm{H}_{13} \mathrm{~N}_{3} \mathrm{OS}\right)$ with the $\mathrm{Co}(\mathrm{II})$ ions gave brown, non-hygroscopic crystals with the molecular formula:.......................... $\left[\mathrm{Co}\left(\mathrm{C}_{13} \mathrm{H}_{13} \mathrm{~N}_{3} \mathrm{OS}\right)_{2}\left(\mathrm{H}_{2} \mathrm{O}\right)_{2}\right]\left(\mathrm{NO}_{3}\right)_{2}$. $\left(\mathrm{H}_{2} \mathrm{O}\right)_{4}$. Ni(II) ions gave brown crystals with the formula:............. $\left[\mathrm{Ni}\left(\mathrm{C}_{13} \mathrm{H}_{13} \mathrm{~N}_{3} \mathrm{OS}\right)_{2}\left(\mathrm{H}_{2} \mathrm{O}\right)_{2}\right]\left(\mathrm{NO}_{3}\right)_{2} \cdot\left(\mathrm{H}_{2} \mathrm{O}\right)_{2}$. The brown crystals also formed with $\mathrm{Cu}$ (II) ions with the formula: $\left[\mathrm{Cu}\left(\mathrm{C}_{13} \mathrm{H}_{13} \mathrm{~N}_{3} \mathrm{OS}\right)_{2}\right]\left(\mathrm{NO}_{3}\right)_{2}$ (Table 1).

\section{Conductivity of the Complexes:}

The conductivity of the formed complexes was measured in DMSO $(0.001 \mathrm{M})$. All the formed complexes gave conductivity in the range 140-179 $\mu \mathrm{S}$ $\left(\mathrm{ohm}^{-1} \cdot \mathrm{cm}^{2} \cdot \mathrm{mol}^{-1}\right)$, which indicates the electrolytic behavior of the complexes(Orabi et al., 2018), which could be formulated generally as $[\mathrm{A}]\left(\mathrm{NO}_{3}\right)_{2}$ form (Table 1)(Orabi, 2008; Orabi et al., 2001; Tyagi et al., 2015). Generally, the conductivity of the formed complexes has the following order (according the ligand type):

\section{Ligand 4 >Ligand $3 \approx$ Ligand $2>$ Ligand 1}

\section{FTIR Spectra}

The FTIR spectra of the target ligands and their complexes were listed in Table 2.
Ligand 2 gave a broad and strong band centered at wavenumber $3454 \mathrm{~cm}^{-1}$ which could be attributed to the stretching vibrational motion for $\mathrm{O}-\mathrm{H}$ group with some inter and/or intra hydrogen bond (Orabi et al., 2018). The obtained result strongly indicated the presence of some tautomerism from the type keto $\leftrightarrow$ enol form. The band which appeared at $3277 \mathrm{~cm}^{-1}$ as strong band could be due to $v_{\mathrm{N}-\mathrm{H}}$ moiety. The stretching vibrational bands which appeared at 1640 and $1604 \mathrm{~cm}^{-1}$ as medium and strong bands respectively could be attributed to the stretching vibration of the $\mathrm{C}=\mathrm{O}$ and $\mathrm{C}=\mathrm{N}$ bonds respectively (Wang et al., 2011). Strong and broad band clearly appeared for all complexes, which ranged at $3632-2700 \mathrm{~cm}^{-1}, 3665-2765 \mathrm{~cm}^{-1}$ and $3651-2804 \mathrm{~cm}^{-}$ ${ }^{1}$ for $\mathrm{Cu}(\mathrm{II}), \mathrm{Ni}(\mathrm{II})$ and $\mathrm{Co}(\mathrm{II})$ complexes respectively, could be assigned as stretching vibration of the water molecules which could present in the formed complexes as water of coordination and water of crystallization. The broadness could be due to: (1) presence of strong inter and/or intra hydrogen bond, (2) presence of partial overlapping of the wave number of $v_{1}$ and $v_{3}$ of the water molecules (Alpert et al., 1970). The stretching vibration band of $\mathrm{C}=\mathrm{O}$ were shifted in all formed complexes which indicate the ligation behavior of this group in complex formation (Table 2). The vibration bands of the nitrate group appeared at the wave number range $1381-1396 \mathrm{~cm}^{-1}$ as strong band, which strongly revealed the ionization nature of this group in the formed complexes(Nakamoto, 1997).The stretching vibration band of the $\mathrm{M}-\mathrm{O}$ bond was appeared at 586-657 $\mathrm{cm}^{-1}$ range for all complexes, while M-N appeared at $514-520 \mathrm{~cm}^{-1}$ as weak band(Orabi et al., 2013). The stretching vibration value is different from metal to another, where it depends on the electronegativity, electronic structure and the mass of the metal ions (Nakamoto, 1997).

The IR spectrum data of the ligand 3 was listed in Table 2. The band which appeared at $3438 \mathrm{~cm}^{-1}$ as shoulder and broad could be due to the presence of the keto $\leftrightarrow$ enol tautomerism with some inter and/or intra hydrogen bond interaction. The strong band which appeared at 3347 and $3270 \mathrm{~cm}^{-1}$ could be assigned as the stretching vibration band due to the $\mathrm{N}-\mathrm{H}$ and $\mathrm{NH}_{2}$. The $\mathrm{v}_{\mathrm{C}=\mathrm{O}}$ appeared at 1634 and $1581 \mathrm{~cm}^{-1}$ as strong bands. The band which centered at $3431 \mathrm{~cm}^{-1}, 3425$ $\mathrm{cm}^{-1}$ and $3439 \mathrm{~cm}^{-1}$ for $\mathrm{Cu}(\mathrm{II}), \mathrm{Ni}$ (II) and $\mathrm{Co}$ (II) complexes respectively could be due to the stretching vibration of the water molecules which could be present in the formed complexes. The $\mathrm{V}_{\mathrm{N}-\mathrm{H}}$ of the ligand completely disappeared in $\mathrm{Cu}$ (II) complexes or gave red shifted (decreasing in wavenumber) in $\mathrm{Ni}$ (II) and $\mathrm{Co}$ (II) complexes enhanced the ligation postulation of the nitrogen of the hydrazine moiety in complexion process. Also, the variation of the stretching vibration of the $\mathrm{C}=\mathrm{O}$, indicates the entrance of this group in complexion process. The stretching vibration band, which centered at 1388, 1387 and $1379 \mathrm{~cm}^{-1}$ as strong band for the $\mathrm{Cu}(\mathrm{II}), \mathrm{Ni}(\mathrm{II})$ and $\mathrm{Co}(\mathrm{II})$ complexes respectively, enhanced the ionic behavior of the nitrate group. The $\mathrm{M}-\mathrm{O}$ and $\mathrm{M}-\mathrm{N}$ were listed in Table 2 as weak bands.

The IR spectrum of the ligand $\mathbf{1}$ gave the characteristic bands for the function groups. The broad 
Ali et al.

Table 1: The physico-chemical properties of the target ligands and their complexes.

\begin{tabular}{|c|c|c|c|c|c|c|c|c|c|}
\hline \multirow{3}{*}{ Compound } & \multirow{3}{*}{ Formula } & \multirow{3}{*}{ M.wt. } & \multirow{3}{*}{ Color } & \multirow{3}{*}{$\begin{array}{l}\text { M.P. } \\
\left(\mathrm{C}^{\circ}\right)\end{array}$} & \multicolumn{4}{|c|}{ Elemental analysis } & \multirow{3}{*}{$\begin{array}{l}\text { Conductivity } \\
\Omega(\mu S)^{\text {a }}\end{array}$} \\
\hline & & & & & \multicolumn{2}{|c|}{$\mathrm{N} \%$} & \multicolumn{2}{|l|}{ M\% } & \\
\hline & & & & & C. & F. & $\mathrm{C}$. & F. & \\
\hline 1 (ligand) & $\mathrm{C}_{10} \mathrm{H}_{9} \mathrm{~N}_{3} \mathrm{O}_{2}$ & 203.20 & Beige & $>300$ & 20.68 & 20.90 & - & - & - \\
\hline 1-Cu complex & {$\left[\mathrm{Cu}\left(\mathrm{C}_{10} \mathrm{H}_{9} \mathrm{~N}_{3} \mathrm{O}_{2}\right)_{2}\right]\left(\mathrm{NO}_{3}\right)_{2} \cdot\left(\mathrm{H}_{2} \mathrm{O}\right)_{2}$} & 629.98 & Green & 283 & 17.79 & 17.66 & 10.09 & 9.98 & 140 \\
\hline 1-Ni complex & {$\left[\mathrm{Ni}\left(\mathrm{C}_{10} \mathrm{H}_{9} \mathrm{~N}_{3} \mathrm{O}_{2}\right)_{2}\left(\mathrm{H}_{2} \mathrm{O}\right)_{2}\right]\left(\mathrm{NO}_{3}\right)_{2}$} & 625.13 & Ice blue & 298 & 17.93 & 17.87 & 9.39 & 9.50 & 155 \\
\hline 1-Co complex & {$\left[\mathrm{Co}\left(\mathrm{C}_{10} \mathrm{H}_{9} \mathrm{~N}_{3} \mathrm{O}_{2}\right)_{2}\left(\mathrm{H}_{2} \mathrm{O}\right)_{2}\right]\left(\mathrm{NO}_{3}\right)_{2}$} & 625.37 & Cream & 290 & 17.92 & 17.70 & 9.42 & 9.36 & 160 \\
\hline 2 (ligand) & $\mathrm{C}_{13} \mathrm{H}_{13} \mathrm{~N}_{3} \mathrm{O}_{2}$ & 243.27 & White & 166 & 17.27 & 17.30 & - & - & - \\
\hline 2-Cu complex & {$\left[\mathrm{Cu}\left(\mathrm{C}_{13} \mathrm{H}_{13} \mathrm{~N}_{3} \mathrm{O}_{2}\right)_{2}\right]\left(\mathrm{NO}_{3}\right)_{2} \cdot\left(\mathrm{H}_{2} \mathrm{O}\right)_{4}$} & 746.14 & Green & 110 & 15.02 & 15.21 & 8.52 & 8.37 & 166 \\
\hline 2-Ni complex & {$\left[\mathrm{Ni}\left(\mathrm{C}_{13} \mathrm{H}_{13} \mathrm{~N}_{3} \mathrm{O}_{2}\right)_{2}\left(\mathrm{H}_{2} \mathrm{O}\right)_{2}\right]\left(\mathrm{NO}_{3}\right)_{2}$} & 705.26 & Green & 170 & 15.89 & 15.95 & 8.32 & 8.64 & 170 \\
\hline 2-Co complex & {$\left[\mathrm{Co}\left(\mathrm{C}_{13} \mathrm{H}_{13} \mathrm{~N}_{3} \mathrm{O}_{2}\right)_{2}\left(\mathrm{H}_{2} \mathrm{O}\right)_{2}\right]\left(\mathrm{NO}_{3}\right)_{2}$} & 705.50 & Brown & 135 & 15.88 & 15.63 & 8.35 & 8.22 & 173 \\
\hline 3 (ligand) & $\mathrm{C}_{13} \mathrm{H}_{13} \mathrm{~N}_{3} \mathrm{O}_{2}$ & 243.27 & Yellow & 267 & 17.27 & 17.13 & - & - & - \\
\hline 3-Cu complex & {$\left[\mathrm{Cu}\left(\mathrm{C}_{13} \mathrm{H}_{13} \mathrm{~N}_{3} \mathrm{O}_{2}\right)_{2}\right]\left(\mathrm{NO}_{3}\right)_{2} \cdot\left(\mathrm{H}_{2} \mathrm{O}\right)_{2}$} & 710.11 & Turquoise & 292 & 15.78 & 15.92 & 8.95 & 8.72 & 151 \\
\hline 3-Ni complex & {$\left[\mathrm{Ni}\left(\mathrm{C}_{13} \mathrm{H}_{13} \mathrm{~N}_{3} \mathrm{O}_{2}\right)_{2}\left(\mathrm{H}_{2} \mathrm{O}\right)_{2}\right]\left(\mathrm{NO}_{3}\right)_{2}$} & 705.26 & Ice blue & 270 & 15.89 & 15.71 & 8.32 & 8.11 & 177 \\
\hline 3-Co complex & {$\left[\mathrm{Co}\left(\mathrm{C}_{13} \mathrm{H}_{13} \mathrm{~N}_{3} \mathrm{O}_{2}\right)_{2}\left(\mathrm{H}_{2} \mathrm{O}\right)_{2}\right]\left(\mathrm{NO}_{3}\right)_{2}$} & 705.50 & Orange & 218 & 15.88 & 15.79 & 8.35 & 8.40 & 169 \\
\hline 4 (ligand) & $\mathrm{C}_{13} \mathrm{H}_{13} \mathrm{~N}_{3} \mathrm{OS}$ & 259.33 & Beige & 156 & 16.20 & 16.29 & - & - & - \\
\hline 4-Cu complex & {$\left[\mathrm{Cu}\left(\mathrm{C}_{13} \mathrm{H}_{13} \mathrm{~N}_{3} \mathrm{OS}\right)_{2}\right]\left(\mathrm{NO}_{3}\right)_{2}$} & 706.22 & Brown & 160 & 15.87 & 15.61 & 9.00 & 8.79 & 160 \\
\hline 4-Ni complex & {$\left[\mathrm{Ni}\left(\mathrm{C}_{13} \mathrm{H}_{13} \mathrm{~N}_{3} \mathrm{OS}\right)_{2}\left(\mathrm{H}_{2} \mathrm{O}\right)_{2}\right]\left(\mathrm{NO}_{3}\right)_{2} \cdot\left(\mathrm{H}_{2} \mathrm{O}\right)_{2}$} & 773.42 & Brown & 106 & 14.49 & 14.58 & 7.59 & 7.56 & 169 \\
\hline 4-Co complex & {$\left[\mathrm{Co}\left(\mathrm{C}_{13} \mathrm{H}_{13} \mathrm{~N}_{3} \mathrm{OS}\right)_{2}\left(\mathrm{H}_{2} \mathrm{O}\right)_{2}\right]\left(\mathrm{NO}_{3}\right)_{2} \cdot\left(\mathrm{H}_{2} \mathrm{O}\right)_{4}$} & 809.69 & Brown & 140 & 13.84 & 13.61 & 7.28 & 7.33 & 179 \\
\hline
\end{tabular}

M.wt. = molecular weight M.P. = melting point C. $=$ calculated

F. = found

${ }^{\mathrm{a}} 10^{-3} \mathrm{M}$ in DMSO, $\mathrm{ohm}^{-1} \cdot \mathrm{cm}^{2} \cdot \mathrm{mol}^{-1}$ 
and medium band which centered at $3438 \mathrm{~cm}^{-1}$ could be due to the keto↔enol tautomerism, meanwhile the $\mathrm{NH}$ and $\mathrm{NH}_{2}$ appeared at 3270 and $3202 \mathrm{~cm}^{-1}$. The $\mathrm{v}_{\mathrm{C}=\mathrm{O}}$ and $\mathrm{V}_{\mathrm{C}=\mathrm{N}}$ appeared at 1653 and $1517 \mathrm{~cm}^{-1}$ respectively. The IR spectra of the complexes $(1-\mathrm{Cu}, 1-$ $\mathrm{Ni}$ and 1-Co) strongly enhanced the ligation properties of the $\mathrm{C}=\mathrm{O}$ and $\mathrm{NH}_{2}$ groups (Alpert et al., 1970; Nakamoto, 1997; Orabi et al., 2018).

The IR spectra of the ligand 4 and their complexes (4-Cu, 4-Ni and $4 \mathrm{Co}$ ) revealed the closed similarity with the ligand 2 and their complexes $(2-\mathrm{Cu}, 2-\mathrm{Ni}$ and 2-Co) (Table 2).

\section{Uv-vis Spectra:}

The uv-vis absorption spectra which produced due to the electronic transitions from the highest occupied molecular orbital (HOMO) to the lowest unoccupied molecular orbital (LUMO) (Pavia et al., 1997), were carried out in ethanolic solution and listed in Table 3.

Generally, the obtained spectra exhibit ligands bands due to $\pi \rightarrow \pi^{*}$ and $\mathrm{n} \rightarrow \pi^{*}$ transitions, which in consequently undergo some red and blue shift on complexation. The bathochromic (red) and hypthochromic (blue) effect strongly revealed the formation of the target complexes. The d-d transition need extra elucidation due to the very small value of the molecular absorptivity $(\varepsilon)$ of this type of transition (Cazedey and Salgado, 2012; Robinson et al., 2014).

\section{Magnetic measurements}

Magnetic susceptibilities of metal complexes were investigated by the Gouy method which involves weighing a sample of the complex in the presence and absence of a magnetic field and observing the difference in weight. The measurements were carried out using Sherwood Scientific's Magnetic Susceptibility Balance (Dunne, 1967; Figgis et al., 1960; Orabi et al., 2018; Teweldemedhin et al., 1996). The mass magnetic susceptibility $\left(\mathrm{X}_{\mathrm{g}}\right)$ was calculated by: $\mathrm{Xg}=\mathrm{LC}\left(\mathrm{R}-\mathrm{R}_{\mathrm{o}}\right) / \mathrm{m} \times 10^{9}$

The magnetic moment measurements of metal complexes are given in Table 3 . The $\mathrm{Cu}$ (II) complexes (2-Cu, 3-Cu, 1-Cu and 4-Cu) has magnetic moment value lies in the range of the planar structure. $\mathrm{Ni}$ (II) and $\mathrm{Co}$ (II) complexes has magnetic moment value in the range of the octahedral structure (Table 3).

\section{Thermal analysis}

The target complexes were subjected to TG-DTA analysis from ambient temperature up to $800^{\circ} \mathrm{C}$ under nitrogen atmosphere.

The obtained metal $\%$ go well with the postulated complexes formula and the residual product was found as MO structure. The thermal decomposition of the 1$\mathrm{Ni}$ was proceeding through three steps, meanwhile 1$\mathrm{Cu}$ and 1-Co were carried out through four steps. The water of crystallization was liberated at DTA temperature $=62{ }^{\circ} \mathrm{C}$ for $1-\mathrm{Cu}$ as endothermic behavior with weight loss revealed two moles of water. Water of coordination was liberated with the same exothermic behavior for 1-Ni and 1-Co complexes. The weight loss in TG analysis, indicates liberation $2 \mathrm{H}_{2} \mathrm{O}$. The thermal decomposition of the ligand proceeds through two steps for all target complexes. The first decomposition step has the following trend:1-Co > 1$\mathrm{Ni}>1-\mathrm{Cu}$ with exothermic behavior.

The 2-Cu complex was thermally decomposed through different steps, where the first step starts at 40 ${ }^{\circ} \mathrm{C}$ and finished at $100{ }^{\circ} \mathrm{C}$ accompanied with DTA peak as endothermic one at $77{ }^{\circ} \mathrm{C}$. The weight loss accompanied with step, according to the TG diagram = 9.82, which go well with the calculated value which obtained from the liberation of 4 molecules from water, which classified as water of crystallization. The ligand decomposition was preceded through exothermic peaks start at $173{ }^{\circ} \mathrm{C}$. Also, liberation of the nitrate group carried out with exothermic peaks. The residue $\%$ goes well with the calculated value of the $\mathrm{CuO} \%$. The 2-Ni complex liberates the two molecules from coordinated water at temperature range finished at $135{ }^{\circ} \mathrm{C}$. The ligand decomposition start decomposed at DTA peak = $150{ }^{\circ} \mathrm{C}$. The residue $\%$ go well with the calculated value as $\mathrm{NiO}$ moiety. 2-Co complex resemble the thermal decomposition behavior of the 2-Ni complex, where the coordinated water liberated with weight loss $\%$ enhanced the liberation of two molecules of water. The residue $\%$ indicates the presence of the $\mathrm{CoO}$ moiety (Aly et al., 2015; Mahmoud et al., 2017).

Generally, the thermal decomposition of the target complexes goes well with the same thermal process. The liberation of the water of crystallization was carried out at DTA peak temperature $=120{ }^{\circ} \mathrm{C}$ for the 3-Cu complex with endothermic behavior. The thermal stability of the ligand in the target complex has the following trend: 3-Co $>3-\mathrm{Ni}>3-\mathrm{Cu}$. The thermal stability of the nitrate group in the complexes has the following trend: 3-Cu $>3-\mathrm{Co}>3-\mathrm{Ni}$. The residual \% was go well with the postulated product formula MO.

The obtained data revealed the distinguishable properties of this ligand than the other. Each complex nearly has the special thermal decomposition trend. 4Co complex gave the largest numbers of decomposition steps meanwhile 4-Cu the lowest. The liberation of the water of crystallization need energy has the following trend: $4-\mathrm{Ni} \approx 4-\mathrm{Co}$. The $\mathrm{TG}$ analysis indicates the liberation of $2 \mathrm{H}_{2} \mathrm{O}$ for $4-\mathrm{Ni}$ and $4 \mathrm{H}_{2} \mathrm{O}$ for $4-\mathrm{Co}$ complex. The thermal decomposition of the coordinated water has the following stability trend: 4$\mathrm{Ni}>4-\mathrm{Co}$. The residual $\%$ of 4-Cu strongly indicate the complicated thermal decomposition process of this complex, meanwhile 4-Ni and 4-Co go well with the MO formula. The principle difference of the ligand 4 with the other ligand, is the presence of the Sulphur atom in its structure, which could be play different role in thermal reactions (Abd El-Halim et al., 2017; Adel S. Orabi et al., 2008).

According to the elemental analysis, conductivity, uv/vis spectra, FTIR, magnetic susceptibility and thermal analysis (DTA/TGA), could be formulated the obtained complexes as shown in Table 1. 
Ali et al.

Table 2: The most effective IR spectra of the target ligands and their complexes

\begin{tabular}{|c|c|c|c|c|c|c|}
\hline Comp. & $\mathrm{V}_{\mathrm{O}-\mathrm{H}}$ & $\overline{v_{\mathrm{N}-\mathrm{H}}}$ & $v_{\mathrm{C}=0}$ & $\mathrm{~V}_{\mathrm{NO}_{3}}$ & $\mathrm{v}_{\mathrm{M}-\mathrm{O}}$ & $\mathbf{v}_{\mathrm{M}-\mathrm{N}}$ \\
\hline 1 (ligand) & 3438 br,m & $\begin{array}{l}3270 \mathrm{~s} \\
3202 \mathrm{sh}\end{array}$ & $\begin{array}{l}1653 \mathrm{~s} \\
1517 \mathrm{~s}\end{array}$ & - & - & - \\
\hline 1-Cu complex & $364-3354 \mathrm{br}, \mathrm{s}$ & $3153 \mathrm{~m}$ & $\begin{array}{l}1653 \mathrm{~s} \\
1582 \mathrm{sh}\end{array}$ & $1381 \mathrm{~s}$ & 657 & 514 \\
\hline 1-Ni complex & $3638-2649 \mathrm{br}, \mathrm{s}$ & & $\begin{array}{l}1672 \mathrm{~s}, \mathrm{br} \\
1622 \mathrm{~s}, \mathrm{br} \\
1562 \mathrm{~s}\end{array}$ & $1381 \mathrm{~s}$ & $528 \mathrm{w}$ & $476 \mathrm{w}$ \\
\hline 1-Co complex & $3645-2675 \mathrm{br}, \mathrm{s}$ & & $\begin{array}{l}1672 \mathrm{br}, \mathrm{s} \\
1622 \mathrm{br}, \mathrm{s} \\
1562 \mathrm{~s}\end{array}$ & $1381 \mathrm{~s}$ & $528 \mathrm{w}$ & $468 \mathrm{w}$ \\
\hline 2 (ligand) & $3454 \mathrm{~s}$, br & $3277 \mathrm{~s}$ & $\begin{array}{l}1640 \mathrm{~m} \\
1604 \mathrm{~s}\end{array}$ & - & - & - \\
\hline 2-Cu complex & $3632-2700 \mathrm{~s}, \mathrm{br}$ & & $1659 \mathrm{~s}$ & $1381 \mathrm{~s}$ & $657 \mathrm{w}$ & $514 \mathrm{w}$ \\
\hline 2-Ni complex & $3665-2765 \mathrm{~s}, \mathrm{br}$ & & $\begin{array}{l}1656 \mathrm{sh}, \mathrm{s} \\
1582 \mathrm{sh}, \mathrm{s}\end{array}$ & $1394 \mathrm{~s}$ & $630 \mathrm{w}$ & $520 \mathrm{w}$ \\
\hline 2-Co complex & $3651-2804 \mathrm{~s}, \mathrm{br}$ & & $\begin{array}{l}1692 \mathrm{sh} \\
1656 \mathrm{~s} \\
1581 \mathrm{~s}\end{array}$ & $1396 \mathrm{~s}$ & $586 \mathrm{w}$ & $520 \mathrm{w}$ \\
\hline 3 (ligand) & 3438 sh.br & $\begin{array}{l}3347 \mathrm{~s} \\
3270 \mathrm{~s}\end{array}$ & $\begin{array}{l}1634 \mathrm{~s} \\
1581 \mathrm{~s}\end{array}$ & - & - & - \\
\hline 3-Cu complex & $3431 \mathrm{~s}, \mathrm{br}$ & - & $\begin{array}{l}1646 \mathrm{~s} \\
1601 \mathrm{~s}\end{array}$ & $1388 \mathrm{~s}$ & $553 \mathrm{w}$ & $540 \mathrm{w}$ \\
\hline 3-Ni complex & $3425 \mathrm{~s}, \mathrm{br}$ & $\begin{array}{l}324 \mathrm{w} \\
3258 \mathrm{w}\end{array}$ & $\begin{array}{l}1646 \mathrm{~s} \\
1600 \mathrm{~s}\end{array}$ & $1387 \mathrm{~s}$ & $560 \mathrm{w}$ & $500 \mathrm{w}$ \\
\hline 3-Co complex & $3439 \mathrm{~s}, \mathrm{br}$ & $3233 w$ & $\begin{array}{l}1648 \mathrm{~s} \\
1600 \mathrm{~s}\end{array}$ & $1379 \mathrm{~s}$ & $547 \mathrm{w}$ & $483 \mathrm{w}$ \\
\hline 4 (ligand) & $3438 \mathrm{br}, \mathrm{s}$ & $3296 \mathrm{~s}$ & $\begin{array}{l}1627 \mathrm{~s} \\
1588 \mathrm{~s}\end{array}$ & - & - & - \\
\hline 4-Cu complex & $3625-3179 \mathrm{br}, \mathrm{s}$ & & $\begin{array}{l}1633 \mathrm{sh} \\
1607 \mathrm{~s} \\
1536 \mathrm{~m}\end{array}$ & $1387 \mathrm{~s}$ & $608 \mathrm{w}$ & $553 \mathrm{w}$ \\
\hline 4-Ni complex & $3651-3088$ br,s & & $\begin{array}{l}1640 \mathrm{sh} \\
1595 \mathrm{sh}, \mathrm{m} \\
1543 \mathrm{sh}, \mathrm{m}\end{array}$ & $1381 \mathrm{~s}$ & $598 \mathrm{w}$ & $489 w$ \\
\hline 4-Co complex & $3632-3036 \mathrm{br}, \mathrm{m}$ & & $\begin{array}{l}1633 \mathrm{sh} \\
1585 \mathrm{sh}, \mathrm{m} \\
1543 \mathrm{sh}, \mathrm{m}\end{array}$ & $1381 \mathrm{~s}$ & $602 w$ & $489 w$ \\
\hline
\end{tabular}

Table 3: The magnetic and electronic spectra of the ligands and their complexes

\begin{tabular}{llllll}
\hline \hline Comp. & $\begin{array}{l}\mathbf{n} \rightarrow \pi * \text { and } \pi \rightarrow \pi * \\
\text { transition }\end{array}$ & $\begin{array}{l}\boldsymbol{\mu}_{\text {eff }} \\
(\mathbf{B . M})\end{array}$ & $\begin{array}{l}\text { Postulated } \\
\text { Structure }\end{array}$ & $\begin{array}{l}\text { Hybrid } \\
\text { orbitals }\end{array}$ & $\mathbf{n}$ \\
\hline 1 (ligand) & $335,277,250,229$ & - & - & - & 1 \\
1-Cu complex & $334,279,228$ & 1.96 & Planar & $\mathrm{dsp}^{2}$ & 2 \\
1-Ni complex & $332,275,229$ & 2.98 & Octahedral & $\mathrm{sp}^{3} \mathrm{~d}^{2}$ & 2 \\
1-Co complex & $332,275,227$ & 4.87 & Octahedral & $\mathrm{sp}^{3} \mathrm{~d}^{2}$ & 3 \\
2 (ligand) & $327,315,273$ & - & - & - & 1 \\
2-Cu complex & $341,277,227$ & 1.80 & Planar & $\mathrm{dsp}^{2}$ & 2 \\
2-Ni complex & $327,315,273,239$ & 3.30 & Octahedral & $\mathrm{sp}^{3} \mathrm{~d}^{2}$ & 3 \\
2-Co complex & $327,314,275,240,224$ & 5.20 & Octahedral & $\mathrm{sp}^{3} \mathrm{~d}^{2}$ & - \\
3 (ligand) & $336,277,250$ & - & - & - & - \\
3-Cu complex & $343,231,208$ & 1.91 & Planar & $\mathrm{dsp}^{2}$ & 1 \\
3-Ni complex & $334,276,230,210$ & 3.51 & Octahedral & $\mathrm{sp}^{3} \mathrm{~d}^{2}$ & 2 \\
3-Co complex & $334,280,230,207$ & 4.92 & Octahedral & $\mathrm{sp}^{3} \mathrm{~d}^{2}$ & 3 \\
4 (ligand) & $347,334,263,214$ & - & - & - & - \\
4-Cu complex & 350 & 1.82 & Planar & $\mathrm{dsp}^{2}$ & 1 \\
4-Ni complex & $342,261,214$ & 3.25 & Octahedral & $\mathrm{sp}^{3} \mathrm{~d}^{2}$ & 2 \\
4-Co complex & $342,261,214$ & 5.08 & Octahedral & $\mathrm{sp}^{3} \mathrm{~d}^{2}$ & 3 \\
\hline \hline
\end{tabular}




\section{In Vitro and In Silico antimicrobial activity}

[A] Antimicrobial activity of compound 1 and its complexes

The obtained data which listed in Table 4 and presented in Figure 1 revealed the promising activity towards the tested Gram positive and Gram negative bacterial also with the target fungi. The obtained data could be summarized as the following:

1- The compound 1 gave the lowest activity towards the target microorganism

2- Generally $\mathrm{Cu}$ (II) complex gave the largest activity which exceeding the market drug

3- Ni (II) and Co (II) complexes are nearly close to each other in their activity.

4- The synthesized compounds have large activity toward the target bacteria rather than the target fungi.

5- All the complexes have activity larger than the parent ligand.

6- The target complexes have competitive force with the reference market drug (Ampicillin)

7- The order of activity towards the E. coli: $1-\mathrm{Cu}>$ Ampicillin $>1-\mathrm{Ni}>1-\mathrm{Co}>1>$ Fluconazole.

8- The order of activity towards the B. Subtils: $1-\mathrm{Cu}>$ Ampicillin $>1-\mathrm{Co}>1-\mathrm{Ni}>1>$ Fluconazole.
9- The order of activity towards the Asp. Niger: Fluconazole $>1-\mathrm{Cu}>1-\mathrm{Co}>1-\mathrm{Ni}>1>$ Ampicillin.

The variation among the activities of the target complexes could be referred to the structure of the obtained complexes, where $\mathrm{Cu}$ (II) complex has square planar structure while Ni (II) and Co (II) has octahedral structure, as mention previously.

The interaction of the target compounds with the tested microorganism was simulated evaluated by using the in Silico tools. The E. coli was used as an example for the target microorganism. The protein which used for docking process was 5C9T. The data which represented in Table 4, strongly forced the obtained activities. The strong interaction of the synthesized compounds with the target protein could be enhanced or retarded the activity of the protein.

In working case, the activity was retarder strongly as the compound bonded strongly with the protein, with one exception for the compound 1 . $\mathrm{Cu}$ (II) complex bonded with the target protein by 5 bonds, while $\mathrm{Co}$ (II) by 3 bonds. Also, the mode of the interaction plays some role about the antimicrobial activity, which clearly shown as $2 \mathrm{D}$ docking view for the target compounds in Figure 2

Table 4: The docking and antimicrobial data for the compound $\mathbf{1}$ and its complexes.

\begin{tabular}{|c|c|c|c|c|c|c|c|}
\hline \multirow{2}{*}{ Comp. } & \multicolumn{3}{|c|}{ Inhibition zone $(\mathrm{mm})^{\mathrm{a}}$} & \multirow{2}{*}{ No. of bonds } & \multirow{2}{*}{ Bond type } & \multirow{2}{*}{ Bond energy ${ }^{b}$} & \multirow{2}{*}{ Binding energy ${ }^{b}$} \\
\hline & E. Coli & B. Subtils & Asp. Niger & & & & \\
\hline Ampicillin & $16 \pm 1$ & $12 \pm 1$ & $0.2 \pm 1$ & & & & \\
\hline Fluconazole & $\mathbf{0}$ & $0.2 \pm 0.5$ & $15 \pm 2$ & & & & \\
\hline \multirow{4}{*}{1 (ligand) } & \multirow{4}{*}{$2 \pm 1$} & \multirow{4}{*}{$3 \pm 0.5$} & \multirow{4}{*}{$3 \pm 0.6$} & \multirow{4}{*}{4} & HD & -1.10 & \multirow{4}{*}{-5.759} \\
\hline & & & & & HD & -2.50 & \\
\hline & & & & & HA & -0.60 & \\
\hline & & & & & $\mathrm{Pi}-\mathrm{H}$ & -1.20 & \\
\hline \multirow{5}{*}{ 1-Cu complex } & \multirow{5}{*}{$18 \pm 2$} & \multirow{5}{*}{$15 \pm 0.8$} & \multirow{5}{*}{$7 \pm 0.5$} & \multirow{5}{*}{5} & HD & -1.80 & \multirow{5}{*}{91.499} \\
\hline & & & & & HD & -1.20 & \\
\hline & & & & & HA & -1.10 & \\
\hline & & & & & HA & -0.03 & \\
\hline & & & & & ionic & -2.10 & \\
\hline \multirow{4}{*}{ 1-Ni complex } & \multirow{4}{*}{$13 \pm 1$} & \multirow{4}{*}{$10 \pm 1$} & \multirow{4}{*}{$5 \pm 0.8$} & \multirow{4}{*}{4} & HD & -5.60 & \multirow{4}{*}{130.065} \\
\hline & & & & & HD & -1.20 & \\
\hline & & & & & HA & -1.20 & \\
\hline & & & & & ionic & -2.70 & \\
\hline \multirow{3}{*}{ 1-Co complex } & \multirow{3}{*}{$12 \pm 0.7$} & \multirow{3}{*}{$11 \pm 0.5$} & \multirow{3}{*}{$6 \pm 1$} & \multirow{3}{*}{3} & HA & 2.90 & \multirow{3}{*}{204.838} \\
\hline & & & & & HA & 25.20 & \\
\hline & & & & & ionic & -3.40 & \\
\hline
\end{tabular}

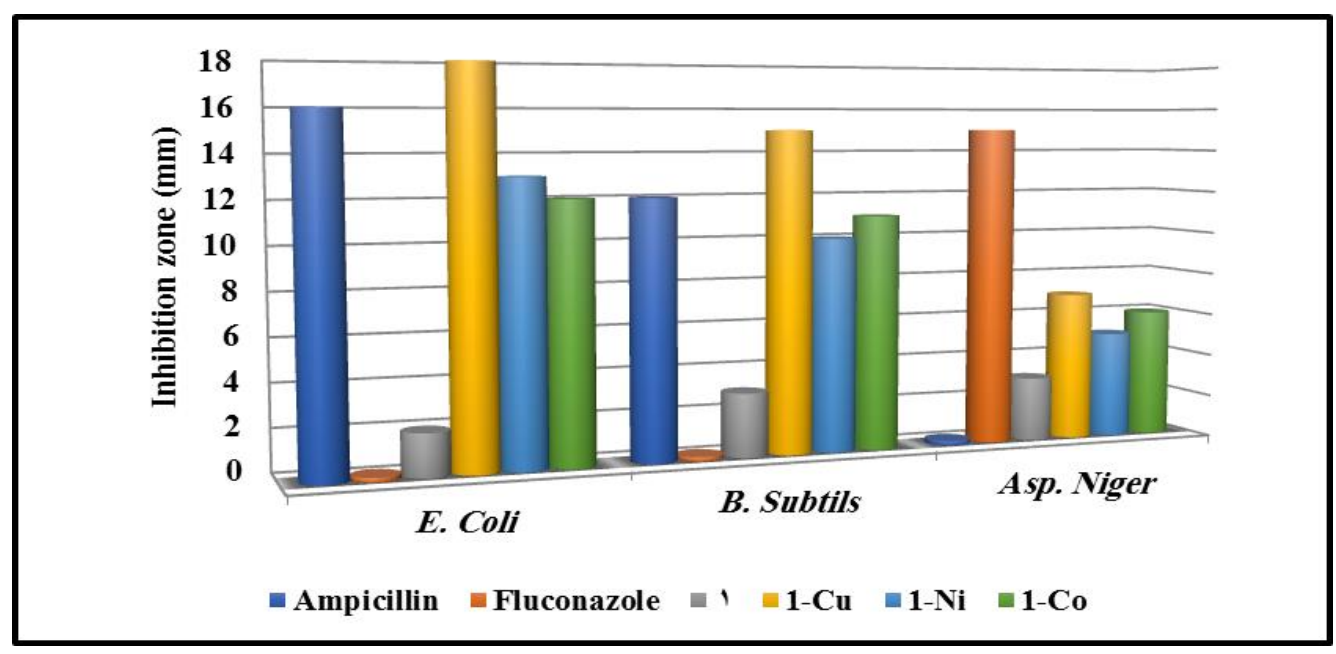

Figure 1: The antimicrobial behavior of the compound 1 and its complexes. 


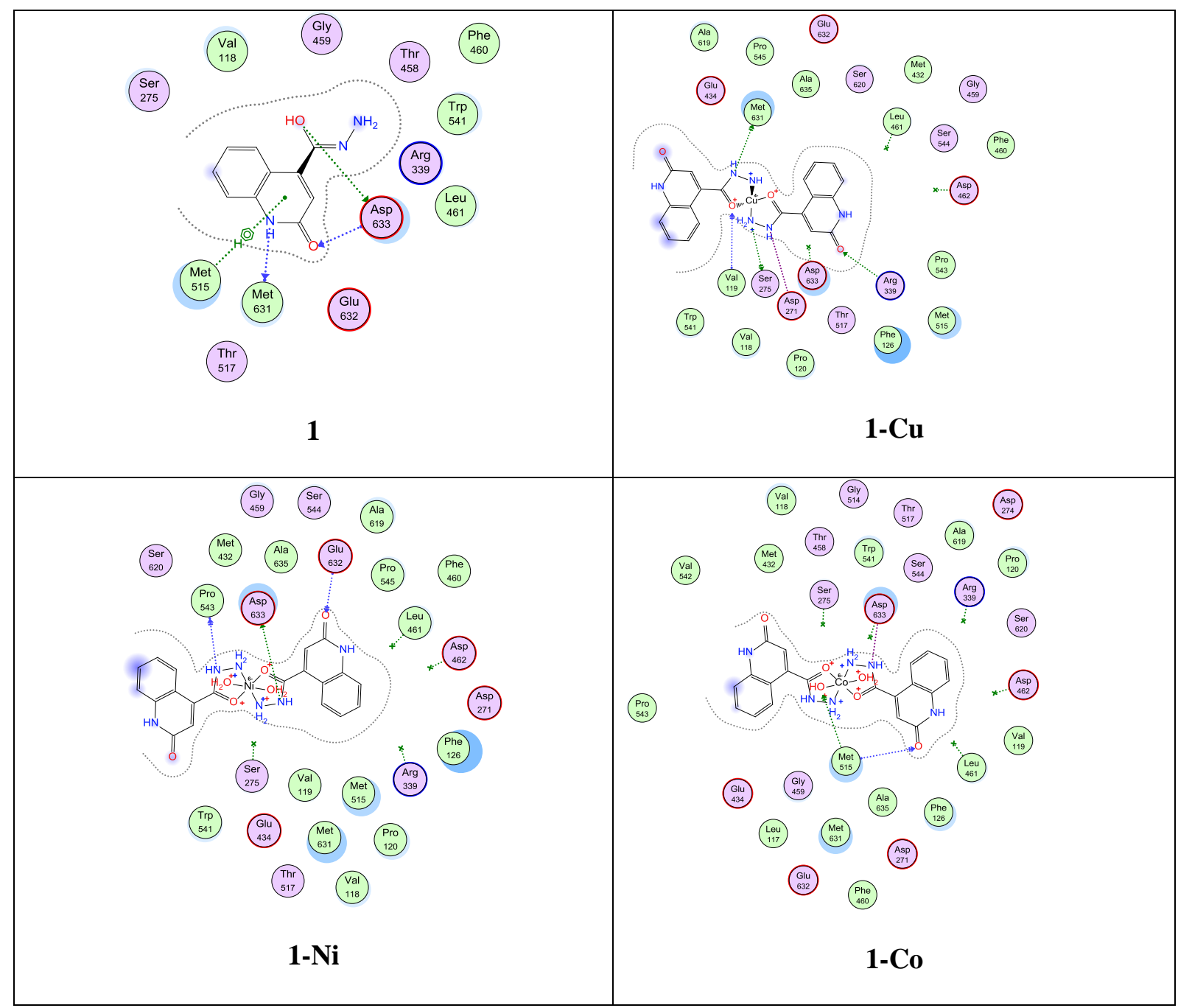

Figure 2: Docking model of the interaction of the compound $\mathbf{1}$ and its complexes with $\boldsymbol{E}$. Coli (PDB code 5C9T) as 2D view.

\section{CONCLUSION}

The prepared compounds and their complexes were characterized using different tools. The obtained data revealed the clear and pure products. The obtained data for the In Vitro antimicrobial activity revealed the promising activity towards the tested Gram positive and Gram negative bacterial also with the target fungi. $\mathrm{Cu}$ (II) complexes gave activity larger than the ampicillin as reference market drug. The interaction of the target compounds with the tested microorganism was simulated evaluated by using the in Silico tools. The E. Coli was used as an example for the target microorganism. The protein which used for docking process was 5C9T. The $\mathrm{Cu}(\mathrm{II})$ complex of the compounds $\mathbf{3}$ and $\mathbf{1}$ gave antibacterial activity greater than the market drug Ampicillin, which advise to use them as antibiotic drug, after pharmaceutical and medicinal treatments. The simulation, modeling and docking tools gave the most useful Gide for select the most suitable compounds for specific action, where the theoretical view nearby coincidence with the laboratory results.

\section{REFERENCES}

ABD EL-HALIM, H.F., G.G. MOHAMED, AND E.A.M.M. KHALIL. 2017. Synthesis, spectral, thermal and biological studies of mixed ligand complexes with newly prepared Schiff base and 1,10-phenanthroline ligands. J. Mol. Struct. 1146: $153-163$

ADEL S. ORABI, H.K. IBRAHIM, E.-S.H. ELTAMANY, AND A. RADWAN. 2008. Studies of some new biologically active ligands and their complexes derived from some transition metal ions. Asian J. Chem. 20: 2022-2036

ALPERT, N.L.L., W.E.E. KEISER, AND H.A.A. SZYMANSKI. 1970. Theory and Practice of Infrared Spectroscopy, Plenum Pre. ed. Plenum Press, New York, USA.

ALY, H.M., M.E. MOUSTAFA, M.Y. NASSAR AND E.A. ABDELRAHMAN. 2015. Synthesis and characterization of novel $\mathrm{Cu}$ (II) complexes with 3substituted-4-amino-5-mercapto-1,2,4-triazole Schiff bases: A new route to $\mathrm{CuO}$ nanoparticles. J. Mol. Struct. 1086: 223-231

BARRY, A.L., AND S.D. BROWN. 1996.

Fluconazole disk diffusion procedure for determining susceptibility of Candida species . J. Clin. Microbiol. 34: 2154-2157.

BÉNARD, C., F. ZOUHIRI, M. NORMAND-BAYLE, M. DANET, D. DESMAËLE, H. LEH, J.-F.F. MOUSCADET, G. MBEMBA, C.M. THOMAS, S. 
BONNENFANT, M. LE BRET, AND J. D'ANGELO. 2004. Linker-modified quinoline derivatives targeting HIV-1 integrase: Synthesis and biological activity. Bioorganic Med. Chem. Lett. 14: 2473-2476

BORIONI, A., C. MUSTAZZA, I. SESTILI, M. SBRACCIA, L. TURCHETTO, AND M.R. DEL GIUDICE. 2007. Synthesis of new 4-heteroaryl-2phenylquinolines and their pharmacological activity as NK-2/NK-3 receptor ligands. Arch. Pharm. (Weinheim). 340: 17-25

BRÄSE, S. 2015. Privileged Scaffolds in Medicinal Chemistry: Design, Synthesis, Evaluation. Royal Society of Chemistry, London, UK.

CAZEDEY, E., AND H. SALGADO. 2012. Spectrophotometric determination of ciprofloxacin hydrochloride in ophthalmic solution. Adv. Anal. Chem. 2: 74-79

CRUICKSHANK, R., J.P. DUGUID, AND R.H.A. SWAIN. 1965. The practice of medical microbiology, 11th ed. E\&S Livingstone Ltd, Edinburgh, London, UK.

DESRIVOT, J., C. HERRENKNECHT, G. PONCHEL, N. GARBI, E. PRINA, A. FOURNET, C. BORIES, B. FIGADÈRE, R. HOCQUEMILLER, AND P.M. LOISEAU. 2007. Antileishmanial 2-substituted quinolines: In vitro behaviour towards biological components. Biomed. Pharmacother. 61: 441-450

DUNNE, T.G. 1967. Magnetic moment measurement of a coordination complex: An experiment in undergraduate inorganic chemistry. J. Chem. Educ. 44: 142-144

EVANS, B.E., K.E. RITTLE, M.G. BOCK, R.M. DIPARDO, R.M. FREIDINGER, W.L. WHITTER, G.F. LUNDELL, D.F. VEBER, P.S. ANDERSON, R.S.L. CHANG, V.J. LOTTI, D.J. CERINO, T.B. CHEN, P.J. KLING, K.A. KUNKEL, J.P. SPRINGER, AND J. HIRSHFIELD. 1988. Methods for drug discovery: development of potent, selective, orally effective cholecystokinin antagonists. J. Med. Chem. 31: 2235-2246

FIGGIS, B.N., J. LEWIS, J. LEWIS, AND R.G. WILKINS. 1960. Magnetochemistry of Complex Compounds in Modern Coordination Chemistry. Interscience, New York.

KOSTOVA, I., AND S. BALKANSKY. 2013. Metal complexes of biologically active ligands as potential antioxidants. Curr. Med. Chem. 20: 4508-4539.

KOUZNETSOV, V. V, L.Y. VARGAS MÉNDEZ, AND C.M. MELÉNDEZ GÓMEZ. 2005. Recent progress in the synthesis of quinolines. Curr. Org. Chem. 9: 141-161

MAHMOUD, M.A., S.A. ZAITONE, A.M. AMMAR, AND S.A. SALLAM. 2017. Synthesis, spectral, thermal and insulin-enhancing properties of oxovanadium(IV) complexes of metformin Schiffbases. J. Therm. Anal. Calorim. 128: 957-969

MANDEWALE, M.C., B.R. THORAT, AND R.S. YAMGAR. 2015. Synthesis and antimycobacterium study of some fluorine containing schiff bases of quinoline and their metal complexes. Der Pharma Chem. 7: 207-215
MUSIOL, R., J. JAMPILEK, V. BUCHTA, L. SILVA, H. NIEDBALA, B. PODESZWA, A. PALKA, K. MAJERZ-MANIECKA, B.OLEKSYN, AND J. POLANSKI. 2006. Antifungal properties of new series of quinoline derivatives. Bioorganic Med. Chem. 14: 3592-3598

NAKAMOTO, K. 1997. Infrared and Raman Spectra of Inorganic and Coordination Compounds, Part II: Application in Coordination, Organometallic, and Bioinorganic Chemistry, 5th ed. Wiley, New York.

ORABI, A.S. 2008. Complexes derived from some biologically active ligands. J. Coord. Chem. 61: 1294-1305

ORABI, A.S., A.M. ABBAS, AND S.A. SALLAM. 2013. Spectral, magnetic, thermal, and DNA interaction of $\mathrm{Ni}(\mathrm{II})$ complexes of glutamic acid schiff bases. Synth. React. Inorganic, Met. NanoMetal Chem. 43: 63-75

ORABI, A.S., K.M. ABOU EL-NOUR, M.F. YOUSSEF, AND H.A. SALEM. 2018. Novel and highly effective composites of silver and zinc oxide nanoparticles with some transition metal complexes against different microorganisms. Arab. J. Chem. doi:10.1016/J.ARABJC.2018.06.016

ORABI, A.S., F.S. DEGHAIDY, H. A. AZAB, AND H. SAID. 2001. Physico-chemical properties of $\mathrm{Nd}(\mathrm{III})$ and $\mathrm{Er}(\mathrm{III})$ complexes with some biological buffer ligands. Synth. React. Inorg. Met. Chem. 31: 695-711

PAVIA, D.L., G.M. LAMPMAN, AND G.S. KRIZ. 1997. Introduction to Spectroscopy, 2nd ed. Saunders Golden Sunburst Series.

ROBINSON, J.W., E.M.S. FRAME, AND G.M. FRAME. 2014. Undergraduate Instrumental Analysis, Seventh. ed. CRC Press Taylor \& Francis Group, New York, NY.

TEWELDEMEDHIN, Z.S., R.L. FULLER, AND M. GREENBLATT. 1996. Magnetic susceptibility measurements of solid manganese compounds with evan's balance. J. Chem. Educ. 73: 906-909

THOMAS, K.D., A.V. ADHIKARI, S. TELKAR, I.H. CHOWDHURY, R. MAHMOOD, N.K. PAL, G. ROW, AND E. SUMESH. 2011. Design, synthesis and docking studies of new quinoline-3carbohydrazide derivatives as antitubercular agents. Eur. J. Med. Chem. 46: 5283-5292

TYAGI, P., S. CHANDRA, B.S. SARASWAT, AND D. YADAV. 2015. Design, spectral characterization, thermal, DFT studies and anticancer cell line activities of $\mathrm{Co}(\mathrm{II}), \mathrm{Ni}(\mathrm{II})$ and $\mathrm{Cu}(\mathrm{II})$ complexes of Schiff bases derived from 4-amino-5-(pyridin-4-yl)-4H-1,2,4-triazole-3-thiol. Spectrochim. Acta-Part A Mol. Biomol. Spectrosc. 145: 155-164

VAVŘÍKOVÁ, E., S. POLANC, M. KOČEVAR, K. HORVÁTI, S. BSZE，J. STOLAŘÍKOVÁ, K. VÁVROVÁ, AND J. VINŠOVÁ. 2011. New fluorine-containing hydrazones active against MDRtuberculosis. Eur. J. Med. Chem. 46: 4937-4945

WANG, Q., Y. PAN1, J. WANG, Q. PENG, H. LUO, AND J. ZHENG1. 2011. Synthesis and biological activities of substituted N'-benzoylhydrazone derivatives. African J. Biotechnol. 10: 1801318021 
تطبيقات عملية الإدخال على بعض المتراكبات الجديدة المشتقة من مشتقات الكينولين الجديدة

ابراهيم احمد على ${ }^{1}$ سحر سعيد احمد السقا2 و محمد حلى عبد الحميد سليمان² و اميمة السيد عبد الباسط محمد3

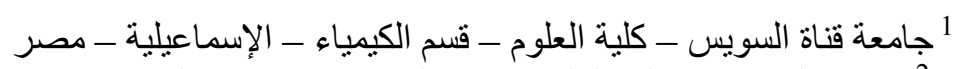

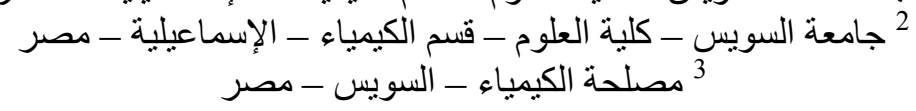

$$
\begin{aligned}
& \text { الملخص العربــي }
\end{aligned}
$$

مشتقات الكينولين الجديدة وكذلك منر اكباتها مع النحاس و النيكل والكوبلت قد نم تحضير ها وتوصيفها باستخدام تحليل العناصر والأشعة تحت الحمر اء و ةالأشعة المرئية والفوق بنفسية وأطياف الرنين النووى المغناطيسى والتحاليل الحرارية وقياس المغناطيسية وكذللك التوصيلية. تم در اسة النمذجة الجزيئية وكذلك عملية الإدخال فى البروتين HepG2 وتمت مناقثة النتائج على ولى E. Coli, Bacillus subtilis and الأسس العلمية السابقة. تمت دراسة النشاطية الميكروبية للمركبات المحضرة مع Aspergillus niger 